Залужний А. Л., аспірант (Національний університет водного господарства та природокористування, м. Рівне)

\title{
СУТНІСТЬ ТА КЛАСИФІКАЦІЯ ПОТРЕБ У МІЖДИСЦИПЛІНАРНОМУ BИMIPI
}

У статті розглянуто проблему сутнісного осмислення потреб, їх структуру, класифікацію, особливість розвитку у метаконтекстуальному вимірі досліджень сучасної гуманітаристики. Крізь призму міждисциплінарного підходу здійснено аналітичний огляд потреб у фізіологічно-біологічному, екологічно-економічному та соціологічному дискурсі. Наголошується на подвійній сутності потреб, які акумулює в собі єдність об'єктивних та суб'єктивних начал. Показано різноманітність потреб, що передбачає їх класифікацію по рівнях, групах, класах, видах, обумовлюючи ієрархічну співвідносність та взаємодію. Акцентується увага на тому, що тільки людина є тим єдиним і унікальним сущим, яка не просто має потреби, але й здатна їх усвідомлювати, формувати, й не лише задовольняти, але й критично переосмислювати, обмежувати.

Ключові слова: потреби, особистість, міждисциплінарний підхід, соціум, фізіологія, екологія, екологічно-економічне мислення, економічні потреби, теорія соціальної дії.

Постановка проблеми. Феномен потреб людини актуалізує дискусійний вектор сучасного соціально-економічного знання, посилюючи проблемне поле міждисциплінарнихо дослідницьких підходів. Саме потреби $\epsilon$ невід'ємною частиною економічних процесів, а степінь їх задоволення - показником економічного і культурного розвитку соціуму. Натомість будь-яка економічна система $є$ ефективною, коли орієнтується не тільки на матеріально-речовинні та технічні характеристики виробничого процесу, але й надає пріоритету людському чиннику, його інтелектуальному, соціально-економічному та духовному потенціалу. Саме тому особливого значення набирає осмислення феномена потреб у контексті різних сфер наукового знання, закладаючи підвалини осмислення сутнісного витлумачення потреб, та специфіки їх функціонування у метаконтекстуальному вимірі фізіологічно-біологічних, екологічно-економічних та соціологічних підходів.

Аналіз останніх досліджень і публікацій. Дослідники відносять 
потреби до основних та найбільш складних і суперечливих проблем, оскільки їхня багатовекторність вивчається різними науками, обумовлюючи врахування природи потреб, особливостей становлення, структури, механізмів формування, закономірностей розвитку, тощо. Так, соціологічна інтерпретація потреб здійснюється у полі експлікації проблем виховання (Е. Дюркгейм), поєднання розмаїття в єдиний однорідний тип (Ф. Гіддінс), інтеріоризації загальноприйнятих норм в процесі спілкування (Д. Парсонс), пошуку соціокультурний цінностей (В. Франкл), тим самим засвідчуючи багатовекторність потребнісної проблематики.

Вивчення потреб в мотиваційній площині здійснюється такими західними психологами як А. Маслоу, Г. Мюррей, Ф. Райс, а на теренах радянської науки такими відомими вченими як К. Леонтьєв, С. Рубінштейн, Л. Виготський та ін.

Значний внесок в розробку теорії та практики феномена потреб громадян у проблемному полі підвищення економічного та соціокультурного добробуту внесли такі вітчизняні (І. Бех, В. Ліснича, С. Мочерний, І. Надольний, Н. Юхименко, В. Шинкарук, О. Яценко та ін.) та зарубіжні (С. Богачов, Л. Булочнікова, Ю. Васильчук, Б. Левін, В. Радаєв та ін.) вчені.

Постановка завдання. У запропоновані статті поставимо завдання експлікації потреб людини, особливостей їх сутнісного тлумачення, структури та особливостей функціонування у метаконтекстуальному просторі соціально-економічного буття людини. Крізь призму міждисциплінарного підходу здійснемо аналітичний огляд потреб у фізіологічно-біологічному, екологічно-економічному та соціологічному дискурсі. Все вище сказане дає підстави для аналітично-дослідницьких проектів висвітлення теоретико-методологічних інтерпретацій потреб в контексті окреслених підходів та усвідомлення їх місця в сучасному наукових розвідках.

Виклад основного матеріалу. Потреби виконують функцію активності, стійкості системи, спрямованої на збереження її складових. Адже саме від їх задоволення або незадоволення залежить життя та розвиток будь-якого живого організму. А відтак, потреби - це стан, властивість, характерні для всьому живого, що «виражає початкову, вихідну форму його активного, вибіркового відношення до умов навколишнього середовища» [2, С. 13-14] з метою здійснення свого розвитку.

Властиво, що в залежності від сфери наукового знання, а саме: фізіології, психології, соціології, філософії та економіки осмислюються різні аспекти ґенези і специфіки функціонування потреб, зумовлюючи проблемність в сутнісному витлумаченні. Адже з врахуванням 
суб'єкта потреб, яким може виступати біологічний організм, індивід, соціум, економічний суб'єкт, соціальні інститути, особистість закладаються основи дослідження потреб різними науковими вченнями. У зв'язку з цим А. Маргуліс та $Є$. Степанов стверджують: «Виявлений на теперішній момент загальнонауковий «стиковий» характер проблематики потреб об'єктивно потребує від представників різних наукових дисциплін об'єднати, інтегрувати дослідницькі зусилля і тим самим зняти надмірну відокремленість різних аспектів аналізу потреб» [3, С. 55].

Так, осмислення фізіологічно-біологічного виміру потреб передбачає їх розгляд крізь призму відповідних активно-спонукаючих станів, які виникають в організмі під впливом зовнішньої природної необхідності, потребуючи пошуку засобів їх задоволення. Даний підхід розглядає людину як цілісну, динамічну, саморегулюючу істоту з особливим наголосом на дослідженні біологічних закономірностей, що властиві для усіх живих організмів. За основу береться об'єктивне розуміння організму, яке в межах своїх життєвих циклів існує в безперервному обміні з середовищем та спонукальному відношенні до його умов. Властиво, що фізіологія людини як сфера наукового знання вивчає цілісність організму не тільки крізь призму «внутрішніх механізмів саморегуляції фізіологічних процесів, але й механізмів, що забезпечують безперервну взаємодію і нерозривну єдність організму з навколишнім середовищем» [7, С. 12]. У поле дослідження потрапляє стан організму в ситуаціях незадоволеності та неспокою, оскільки виникає необхідність у певних умовах, потребах, яких не вистачає для нормального розвитку й підтримки життєвих сил. Саме розроблена П. Анохіним теорія функціональних систем визначає фізіологічну структуру поведінкового акту цілеспрямованої діяльності людського організму, постаючи послідуючим розвитком вчення І. Павлова про вищу нервову діяльність. Цілеспрямована поведінка живого організму забезпечується динамічними самоорганізованими системами, компоненти якої перебувають у постійній взаємодії з метою задоволення певної потреби. Акценти робляться на біологічному витлумаченні людини, вибір поведінки якої визначається акумуляцією сигналів із зовнішнього середовища (афферентним синтезом), формуючи програму дій виконавчим органам, а потреба в даному контексті виступає відправним пунктом всієї системи стимулювання. Натомість, поза за межами залишаються пояснення щодо вищих проявів психічних функцій свідомості, творчості, натхнення та ін., спонукаючи до виникнення нових підходів у нейронній доктрині, зокрема розгляду нейрона з позицій «активного еле- 
менту». У сучасній нейрофізіології дослідження нервової активності (нейронна доктрина) спонукає до переосмислення «нейрона як деякого пасивного елементу, до якого по синаптичним входам приходять збудження і викликають в ньому певні електичні чи хімічні процеси» [4, С. 31], закладаючи грунт для нових академічних студій. Відповідно до парадигмальних засад «активної нейрофізіології» створена мозком модель майбутнього передбачає не тільки реакцію на зовнішні стимули, але й цілепокладання, що виробляється еволюцією, досвідом всього життя та навчанням, супроводжуючись побудовою нових систем і нових елементів індивідуального досвіду.

Все вище зазначене показує, що окреслений підхід в силу своєї специфіки зосереджується на фізіологічному механізмі їх виникнення в матеріальних субстратах людини, які спрямовані на забезпечення її фізичного існування. А потреби як і емоції та потяги виступають необхідними складовими елементами біологічної сутності людини.

Властиво, що видатний вчений біолог, зоолог, еколог М. Реймерс визначає потреби людини як «систему вимог до навколишнього середовища» [5, С. 284] в зрізі окреслення шляхів взаємодії біосфери та людини, суспільства та природи, закладаючи вагоме підґрунтя для становлення соціально-економічної екології як переходу від екології природи до екології людини та суспільства. Відбувається формування нового екологічного мислення у площині якого співвідношення «людина - потреби» перебувають у тісному взаємозв'язку з співвідношенням «організм - середовище», оскільки рівень якісності людського буття в аспекті фізичного, психічного, соціального благополуччя визначається мірою взаємодії та використання середовища. Середовище при такому підході редукується до розмаїття природних та соціальних явищ, процесів та об'єктів (природного середовища, квазіприродного середовища, що передбачає всі модифікації природного, артеприродного середовища як штучно створеного світу та соціального середовища як культурно-психологічного, політичного, інформаційного клімату, створеного для людини суспільством), а якість життя людини - до міри взаємодії і використання його з метою задоволення потреб.

Вчений слідом за В. Вернадським розглядає людину як живу речовину, невідокремлену від біосфери, яка перебуває у безперервних біолого-енергетичних, хімічних, інформаційних зв'язках з природою й здійснює вагомий вплив на їі стан. На його думку, антропогенна трансформація цілісності «людина - природа» на взаємодію «споживач - ресурси», «природа - форми господарства» призводить до порушення екологічної рівноваги й неспроможності біосфери зві- 
льнитися від деструктивного впливу людської діяльності. У дію вступає закон Б. Коммонера «ніщо не дається даремно». У даному контексті М. Реймерс наголошує на неможливості виконання найважливішого екологічного правила щодо «приведення темпів експлуатації природних систем в рівність 3 інтенсивністю самовідтворення цих систем» [5, С. 273], згідно якого природно-ресурсний потенціал повинен перевершувати, або дорівнювати рівню вилучених ресурсів 3 природного середовища, забезпечуючи можливість саморегуляції біосфери.

Натомість, господарська діяльність людини здійсню тиск як на системи безпосереднього впливу, так і на надсистеми, що виконують функцію нівелювання негативних трансформацій (принцип Ле Шательє-Брауна, згідно якого в ситуації зовнішнього впливу, який виводить систему із стану стійкої рівноваги, відбувається зміщення в тому напрямку, в якому ефект зовнішнього дії послаблюється), порушуючи водночас закон внутрішньої динамічної рівноваги. Саме нові форми господарювання детермінують низку цепних реакцій в природі, підводячи стан сучасної людини на межу еволюційної катастрофи. А тому, М. Реймерс, визначаючи рівень розвитку антропосистеми в екосистемі як загрозливий, розробляє «екологічний маніфест» [5, С. 359-363], щодо обґрунтування необхідності регуляції відносин між біосферою та людством, людською діяльністю та зміненою під ії впливом природою, що потребує не тільки процесів самоорганізації, але і свідомого позитивного втручання.

Таке загострення уваги на екологічних проблемах обумовлене ситуацією не контрольованості розвитку людства у проблемному полі взаємодії господарської діяльності з навколишнім середовищем в системі «людина - природа», звільняючи місце «часу Розуму». На думку вченого, нова епоха основоположним ресурсом визначає час, оскільки людина повинна навчитися змінюватися під відповіддю бумеранга зруйнованої нею природи, позаяк ні в якому разі не повинна порушуватися рівновага між тиском на середовище та можливістю відтворення його. Саме тому ідея екологізації з вимогами зменшення тиску на середовище життя та усвідомлення виснаження недостатності природно-ресурсного потенціалу закладає засади нового екологічного мислення та переосмислення місця та ролі потреб в людській життєдіяльності. Адже у цьому випадку потреби повинні формуватися крізь призму усвідомлення залежності людини як від первинної природи, так і антропогенних трансформацій, тих істотних змін, які вона здійснила в біосфері. Хоча потреби є якісно і кількісно неоднорідними, втім виникає можливість обгрунтування інтеграль- 
но-ситсемної сукупності в намаганні створити цілісного підходу до їх розуміння.

А відтак, своєрідна класифікація потреб з врахуванням екологічної компоненти (соціально-економічна екологія людини), зокрема екологічного підходу до розуміння людини в контексті ієрархії природних систем пропонується, [5] з своєрідним поділом потреб на:

- речовинно-енергетичні та інформаційні;

- першочергові та віддалені;

- раціональні та ірраціональні;

- прямі та компенсаторні.

Властиво, що традиційний поділ потреб на матеріальні та духовні, автор заміню, на його думку, на більш «ємкі та адекватні» [5, C. 302], речовинно-енергетичні та інформаційні. Шість груп (А-Є) включає в себе 56 групових різновидів. Водночас окреслена схема акумулює такі основі групи потреб, які вибудовується на концептуалізації виведення потреб з біосоціальної структури людини. Зазначений підхід розглядає людину як надзвичайно складну систему, яка включає шість взаємопов'язаних підсистем: анатомно-фізіологічну, еколого-поведінкову, етнічну, трудову, соціальну та економічну. Зазначене розуміння людини стає необхідними для виявлення людських нужд в їх системному об'єднанні і виступає істотною детермінантою виявлення таких шести груп основних потреб (підсистем) як от: біологічні, еколого-поведінкові (психологічні), етнічні, соціальні, трудові та економічні (з врахуванням їх диференціації на вроджені та набуті). Таке розмаїття потреб значною мірою визначає специфіку світогляду людини, мислення, почуттів, характер поведінки.

Зокрема біологічні потреби зосереджують потреби в їжі, воді, повітрі, теплі, продовжені роду та ін.; еколого-поведінкові - в стилі життя, темпі спілкування, екологічно комфортного житла, квітучого краю та ін.; етнічні - етнічна самостійність пейзаж Вітчизни; соціальні - свобода, моральні норми спілкування, користування культурними цінностями, духовними та ін.; трудові - можливість праці, заохочення праці, потреба в пізнанні та ін.; економічні - потреби в їжі, одежі, житла у відповідності 3 анатомко-фізіологічними [5, С. 304-315].

Але особлива роль даного підходу це формування нового екологічно орієнтованого світогляду, що уможливлює утвердження нового поняття «екологічні потреби» як потреба в існуванні сприятливого для людського буття природного середовища. В основі екологічного мислення людина розглядається як підсистема, а якісне задоволення потреб викликає необхідність оптимізації усіх підсистем. Як бачимо в зазначених парадигмальних зрушеннях відстежується своєрідне явище екологізації потреб людини, що надзвичайно актуаль- 
ним для сучасного буття суспільства і спонукає до осмислення потреб у контексті соціологічних підходів.

Інтерпретації потреб в соціологічному дискурсі редукує їх до об'єктивних явищ соціальної системи, що виражають запити (нужду) особистості, соціальної групи або соціуму загалом у відповідних умовах існування й необхідності засобів і видів діяльності задля забезпечення нормального функціонування та розвитку. Потреби в даному контексті формуються під впливом суспільних відносин, законів суспільного розвитку та соціальних умов незалежно від психофізичних характеристик особистості. Таке бачення, значною мірою, обумовлене сформованим в соціологічній науці «об'єктно-репродуктивним підходом», згідно якого «особистість, - як стверджує З. Галєєв, - розглядається тільки як об'єкт управління програм зовнішнього виховного впливу з боку офіційних інститутів соціалізації та соціальної політики» $[1$, С. 200]. Тоді як процес соціалізації вчений пропонує досліджувати в зрізі діалогічно-креативного наслідування соціокультурного досвіду культури, тих смислів та значень, які необхідні для задоволення особистісних потреб.

Загалом, соціологічна інтерпретація потреб здійснюється у полі експлікації проблем соціалізації, соціальної ідентичності та аналізу їх ролі у соціальній поведінці суб'єктів й суспільного розвитку. В цьому процесі особливе місце займає сім'я, етнос, субкультура, засоби масової інформації держава, які визначають стиль життя та моделі поведінки. Зокрема, процеси соціалізації забезпечує включення індивіда в систему суспільних відносин, потребуючи ефективного функціонування політичної, економічної та освітньої системи, діяльності інституцій, які сприяють реалізації прав і свобод громадян, їх соціокультурному становленню. Внаслідок соціалізації біологічні потреби наповнюються соціальним змістом, сприяючи реалізації індивіда як повноцінного члена суспільства, носія соціальної ролі та суб'єкта соціальної дії. Адже суспільне буття уможливлюється завдяки соціальних дій, інтеракцій (взаємодій), соціальних ролей (інтеграція), які включають дії людей в соціальну систему норм і взірців поведінки

У вище зазначеному сенсі досить неординарною, на нашу думку, виступає запропонована Т. Парсонсом теорія соціальної дії, що спонукає до розуміння потреб суб'єкта у тісному зв'язку з ситуацією. Вказана ситуація обумовлюється часом, об'єктивними передумовама та суб'єктивним змістом. Водночас визначаються базові потреби соціальних дій, які складають основні умови існування соціальної системи, до яких відносять:

- потреби адаптації як реагування на зміни оточуючої дійсності;

- потреби ціледосягнення як вимоги в досягненні загальнозначимих цілей, з метою спрямованості розвитку соціальної системи; 
- потреби інтеграції як необхідність інституалізації соціальних норм;

- потреба латентності як затребуваність норм та цінностей задля збереження міцності системи соціальних дій та стримування напруги між діючими суб'єктами.

Окреслені потреби обумовлюють функціонування чотирьох взаємопов'язаних підсистем. Основу цих підсистем становлять економічна, що сприяє забезпечення матеріальних благ (адаптація), політична - для визначення цілеспрямованість соціальної активності (ціледосягнення), правової - для упорядкування норм між індивідами та інститутами (інтеграція), соцієтальної як збереження нормативних взірців (латентність).

Властиво, що Т. Парсонс [10] в основу взаємодії людей покладає не гроші та владу, а вимоги соціального порядку та солідарність. Адже соціальна дія як взаємодія виступає такою соціальною поведінкою, що здійснюється під впливом внутрішньої мотивації, спрямовуєтьсяї на зовнішню ціль та підпорядковується соціальним регуляторам (ціннісними та нормативним стереотипами).

Висновки. Таким чином, потреба $є$ визначальною характеристикою всього живого, передумовою існування будь-якого живого організму, джерелом активності та рухомою силою поведінки. Розмаїття підходів щодо розуміння потреб дає можливість визначити низку сутнісних ознак до яких зводяться потреби, як от:

- нужда, необхідність як те, що необхідне для живого організму (С. Рубінштейн, А. Здравомислов, Д. Узнадзе);

- відносини між суб'єктом та середовищем ( Д. Леонтьєв), людиною та світом (М. Кузнєцов);

- вимоги до середивища (М. Реймерс);

- суперечність між наявним та бажаним (М. Михайлов), соціальним суб'єктом та об єктивними умовами життєдіяльності (М. Ханова);

- детермінанта соціальні дії (Т. Парсонс).

Виокремлення сутнісних ознак в проблемному полі різноманітності понятійних дефініцій феномена потреб уможливлює окреслення основних властивості потреб, а саме: почуття незадоволеності та дискомфорту, ускладнення потреб в процесі онтогенези, сигналізації як донесення про необхідність чогось, що викликало зміну біологічного чи психологічного стану, емоційне переживання (позитивне - в разі задоволення та негативне - в разі посилення інтенсивності потреби), системність потреб та їх ієрархічність, мотиваційна спонукальність до дії, визначення спрямованості поведінки, забезпечення безперервності людського самоздійснення.

Водночас потреби різноманітні і підлягають диференціації, кла- 
сифікуючись і структуруючись по рівнях, групах, класах, видах, перебуваючи у ієрархічній співвідносності та взаємодії. Значна кількість класифікацій обумовлена теоретико-методолгічними підходами відповідної сфери наукового знання та притаманних для них шкіл і напрямів, що засвідчує їх складність та неоднозначність. Проблемність створення єдино вірної класифікації також випливає з наявності необмеженої кількості потреб, їх трансформаційних зрушень, унеможливлюючи їх цілісну типологізацію. У запропонованій статті пропонується використання традиційного підходу, який зводяться до поділу усіх потреб на матеріальні (біологічні), соціальні та духовні (ідеальні), що постає науково виправданим в умовах застосування міждисциплінарного підходу, позаяк лежать в основі будь-якої класифікації, незалежно від наукової сфери. Адже потреби постають вагомою детермінантою поведінки людей, їх діяльності та самореалізації позаяк виражають прагнення до тих умов, які потрібні для нормального фізичного, психічного та духовно-морального стану. У даному контексті акцентується увага на тому, що тільки людина є тим єдиним і унікальним сущим, яка не просто має потреби, але й здатна їх усвідомлювати, формувати, й не лише задовольняти, але й критично переосмислювати, обмежувати.

1. Галлеев Г. З. Социализация личности: методологический аспект. Вестник экономики. Права и социологии. 2012. № 2. С. 200-203. 2. Здравомыслов А. Г. Потребности. Интересы. Ценности. М. : Политиздат, 1986. 223 с. 3. Маргулис А. В. (Белгород), Степанов Е. И. Потребности человека: методологические проблемы комплексного исследования (Аналитический обзор литературы). Вопросы философии. 1986. № 4. С. 54-69. 4. Нейрон. Обработка сигналов. Пластичность. Моделирование. Фундаментальное руководство / Ю. И. Александров и др. Тюмень : Издательство Тюменского государственного университета, 2008. 548 с. 5. Реймерс Н. Ф. Экология (теории, законы, правила, принципы и гипотезы. М. : Журнал «Россия Молодая», 1994. 367 с. 6. Рубинштейн С. Л. Основы общей психологии. 2-е изд. Серия: Мастера психологии. СПб. : Издательство «Питер», 2002.720 с. 7. Физиология человека. Ф50 3-е изд., перероб. и доп. / под редакцией Г. И. Косицкого. М. : Медицина, 1985. 544 с. 8. Ханова Марина. Роль потребностей в формировании социальных субъектов. Грамота. 2013. № 8 (34) : в 2-х ч. Ч. ІІ. С. 190-193. 9. Щербатых Ю. В. Общая психология. СПб. : Издательство «Питер», 2008. 272 с. 10. Parsons T. The social System. Glencoe, 1951. P. 41-42.

\section{REFERENCES:}

1. Halleev H. Z. Sotsializatsiia lichnosti: metodolohicheskii aspekt. Vestnik ekonomiki. Prava i sotsiolohii. 2012. № 2. S. 200-203. 2. Zdravomyslov A. H. Potrebnosti. Interesy. Tsennosti. M. : Polytyzdat, 1986. 223 s. 3. Marhulis A. V. 
(Belhorod), Stepanov E. I. Potrebnosti cheloveka: metodolohicheskie problemy kompleksnoho issledovaniia (Analiticheskii obzor literatury). Voprosy filosofii. 1986. № 4. S. 54-69. 4. Neiron. Obrabotka sihnalov. Plastichnost. Modelirovanie. Fundamentalnoe rukovodstvo / Yu. I. Aleksandrov i dr. Tiumen : Izdatelstvo Tiumenskoho hosudarstvennoho universiteta, 2008. $548 \mathrm{~s}$. 5. Reimers N. F. Ekolohiia (teorii, zakony, pravila, printsipy i hipotezy. M. : Zhurnal «Rossiia Molodaia», 1994. 367 s. 6. Rubinshtein S. L. Osnovy obshchei psikholohii. 2-e izd. Seriia: Mastera psikholohii. SPb. : Izdatelstvo «Piter», 2002. 720 s. 7. Fiziolohiia cheloveka. F50 3-e izd., pererob. i dop. / pod redaktsiei H. I. Kositskoho. M. : Meditsina, 1985. 544 s. 8. Khanova Marina. Rol potrebnostei v formirovanii sotsialnykh subektov. Hramota. 2013. № 8 (34) : v 2-kh ch. Ch. II. S. 190-193. 9. Shcherbatykh Yu. V. Obshchaia psikholohiia. SPb. : Izdatelstvo «Piter», 2008. 272 s. 10. Parsons T. The social System. Glencoe, 1951. P. 41-42.

Рецензент: д.е.н., професор Созонець І. Л. (НУВГП)

Zaluzhnyi A. L., Post-graduate Student (National University of Water and Environmental Engineering, Rivne)

\section{THE ORETICAL ESSENCE AND CLASSIFICATION OF NEEDS IN THE INTERDISCIPLINARY FORMAT}

The article devoted to the problem of the essential understanding of needs, their structure, classification, peculiarity of development in the transdisciplinary dimension of the research of modern humanities. An analytical review of the needs for physiological-biological, ecologicaleconomic and sociological discourse are determined through the prism of an interdisciplinary approach. It emphasizes the double essence of the needs, which accumulates in itself the unity of objective and subjective principles.

In this article much attention is paid to the formation of a new environmentally oriented worldview of M. Reimers, which makes it possible to establish a new concept of "environmental needs" as a need for the existence of a favorable environment for human existence. At the heart of ecological thinking people are seen as a subsystem, and qualitative satisfaction of needs causes the need for optimization of all subsystems. In the above paradigmatic shifts, a peculiar phenomenon of ecologization of human needs is observed, which is extremely important for the modern life of society. It is noted that needs are a significant determinant of people's behavior, their activities and self-realization. Also in the article are determined that needs express a desire for the conditions that are 
necessary for a normal physical, mental, spiritual and moral state. A variety of needs which presupposes their classification by levels, groups, classes, types, causing hierarchical correlation and interaction are highlighted.

The problem of creation of the only correct classification, which is due to the theoretical and methodological approaches of the corresponding sphere of scientific knowledge and the schools and directions inherent to them, the presence of unlimited number of needs, makes it impossible to integrate the typology are investigated. In the article are determined that only a person is the only and unique being that does not just needs, but also able to understand, shape, and not only satisfy, but also critically rethink, limit.

Keywords: needs, personality, interdisciplinary approach, socium, physiology, ecology, ecological-economic thinking, economic needs, theory of social action.

Залужный А. Л., аспирант (Национальный университет водного хозяйства и природопользования, м. Ровно)

\section{СУЩНОСТЬ И КЛАССИФИКАЦИЯ ПОТРЕБНОСТЕЙ В МЕЖДИСЦИПЛИНАРНОМ ИЗМЕРЕНИИ}

В статье рассмотрена проблема сущностного осмысления потребностей, их структуру, классификацию, особенность развития в метаконтекстуальном измерении исследований современной гуманитаристики. Сквозь призму междисциплинарного подхода осуществлен аналитический обзор потребностей в физиологически биологическом, экологически экономическом и социологическом дискурсе. Отмечается двойной сущности потребностей, которые аккумулирует в себе единство объективных и субъективных начал. Показано разнообразие потребностей, что предусматривает их классификацию по уровням, группах, классах, видах, обусловливая иерархическую соотносительность и взаимодействие. Акцентируется внимание на том, что только человек является единственным и уникальным сущим, который не просто нуждается в потребностях, но и способен их осознавать, формировать, не только удовлетворять, но и критически переосмысливать, ограничивать. Ключевые слова: потребности, личность, междисциплинарный подход, социум, физиология, экология, экологически экономическое мышление, экономические потребности, теория социального действия. 